
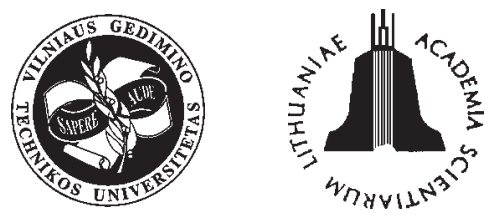

JOURNAL OF CIVIL ENGINEERING AND MANAGEMENT

http:/www.jcem.vgtu.lt

2005, Vol XI, No 2, 121-127

\title{
EXPERIMENTAL RESULTS OF FATIGUE AND SUSTAINED LOAD TESTS ON AUTOCLAVED AERATED CONCRETE
}

\author{
Erich Raue, Enrico Tartsch \\ Bauhaus-University Weimar, Dept of Reinforced Concrete Structures, \\ Marienstrasse 13, 99421 Weimar, Germany.E-mail: erich.raue@bauing.uni-weimar.de \\ E-mail: enrico.tartsch@bauing.uni-weimar.de
}

Received 23 Dec 2004; accepted 28 Apr 2005

\begin{abstract}
The fatigue strength of concrete is lower than its static strength. An attempt was made to accelerate the destabilisation process due to microcracking by the application of fatigue loads. The aim of this was to get ready access to information about concrete's sustained loading strength. The fatigue strength of autoclaved aerated concrete (AAC) was observed by applying cyclic loads to unreinforced cylinders. AAC was found to be less sensitive to fatigue loads than lightweight concrete. The fatigue tests were supplemented by tests using sustained loads. It could be assumed that the behaviour under both static and fatigue loads was comparable with that of lightweight and normal concrete. A substantial influence of load duration was found, especially at high load levels.
\end{abstract}

Keywords: autoclaved aerated concrete, AAC, fatigue strength, sustained loading strength, sinusoidal loading, stiffness degradation, Smith diagram, S/N plot.

\section{Introduction}

Sustained loads lead to the destabilisation and failure of concrete at lower load levels than short term loads. Within the design process, damage mechanisms due to sustained loads are calculated by the reduction factor $\alpha$. The value of $\alpha$ depends on the material. According to DIN $1045-1, \alpha$ is 0,85 for normal concrete and 0,80 for lightweight concrete (LAC). As yet, no clear data exist with regard to the sustained loading strength for autoclaved aerated concrete (AAC).

Experimental investigations into sustained loading strength involve a large expenditure of time, since it must be guaranteed that certain loads can be resisted for a theoretically infinite time span. In order to be able to make clear statements at short notice about the sustained loading strength of AAC, it was necessary to find a way of accellerating the damage mechanisms.

It is known that cyclic loads can lead to failure at lower levels than sustained loads. This can be traced to fatigue. Among other things, the stress range $\left(\sigma_{\mathrm{r}}\right)$ and the mean stress $\left(\sigma_{\mathrm{m}}\right)$ have a substantial influence on fatigue. The greater the mean stress and the stress range, the earlier fatigue failure occurs. In addition, the damage mechanisms are accelerated by reversed loading.

When $o_{r}$ approaches zero, a repeated load becomes a sustained load. Thus from a physical point of view, correlations exist between fatigue and sustained loads. This consideration represents the basis for the fatigue tests conducted on autoclaved aerated concrete. If the investigations show that, in principle, the fatigue strength of AAC resembles others, it can be safely assumed that the sustained loading strength does not differ substantially.

Fatigue tests on approximately 70 unreinforced specimens made of AAC were carried out at the Bauhaus-University Weimar. Further 40 tests applying sustained loads were also conducted. In these tests, applied loads were maintained at constantly set load levels. Finally, the behaviour of AAC under sustained loads was compared with its fatigue behaviour.

\section{Concrete texture and cracking mechanism}

Concrete generally is understood to be a two-component system. The matrix, consisting of hardened cement paste, is interspersed with aggregate particles of differing size. According to [1], failure is substantially influenced by the rigidity of the aggregate. If this rigidity is greater than that of the matrix (as in case with normal concrete), cracks appear in the contact zone between aggregate and matrix. In case of lightweight concrete, cracks run through aggregate particles.

Autoclaved aerated concrete does not contain large aggregate particles. Nevertheless, it can still be considered a two-component system. The matrix of aerated concrete is interspersed with air voids. These can be seen as aggregate particles with a zero rigidity. Thus the fail- 
ure process seems to be comparable with that of lightweight concrete.

The failure of concrete can be attributed to cracking and crack growth processes. Under high static loads, the cracks grow due to creep processes, ultimately leading to failure [2]. At the same time, compressive strength rises due to progressive hydration.

In the case of normal concrete, failure due to constant static load after sufficiently long loading period can be ruled out. The critical loading period is given as 310 days [2]. In case of lightweight concrete, post-hardening does not lead to a significant increase in compressive strength. It is virtually impossible to compensate for the destabilisation process due to cracking. A critical loading period, therefore, cannot be indicated as it can for normal concrete.

After autoclaving, the hardening process of AAC can be regarded as final. Thus AAC and lightweight concrete may be said to behave similarly.

\section{Fatigue tests}

Fatigue tests were conducted under a standard atmosphere on unreinforced cylinders $(d=100 \mathrm{~mm}$, $1=200 \mathrm{~mm}$ ) made of AAC. Before the tests the specimens were dried at $50{ }^{\circ} \mathrm{C}$ and afterwards stored in the laboratory for 3 months. The humidity equilibrium of the specimens was reached at 2,3 M.-\%. The density of the AAC in the dry state was determined to be $6,8 \mathrm{kN} / \mathrm{m}^{3}$. Loads were applied perpendicularly to the direction of expansion. A detailed description of the fatigue tests is given in [3].

\subsection{Investigation procedure}

The main fatigue test programme was supplemented by additional investigations. Before the fatigue tests, the compressive strength $\left(\mathrm{f}_{\mathrm{cm}}\right)$ of the specimens was determined on 10 specimens $\left(7,9 \mathrm{~N} / \mathrm{mm}^{2}\right.$, coefficient of variation $\mathrm{COV}=0,02)$. The same specimens as for the fatigue tests were used. The chosen loading rate for the static tests was $0,1 \mathrm{~N} / \mathrm{mm}^{2}$ per second.

Fatigue tests were carried out using sinusoidal loading (Fig 1) at $5 \mathrm{~Hz}$. Uniaxial constant amplitude fatigue loads (compression-compression) were applied. The maximum number of cycles was limited to $10^{6}$.

It was decided to produce three curves. The minimum stress was kept constant and the maximum stress varied in each test series (Fig 1). The servo-hydraulic fatigue testing machine (Schenck: PSB 500/2) was used.

The deformations were indirectly measured by three inductive displacement gauges shifted by $120^{\circ}$. Longitudinal strains were calculated by dividing the displacement of the pressure plates by the specimen length.

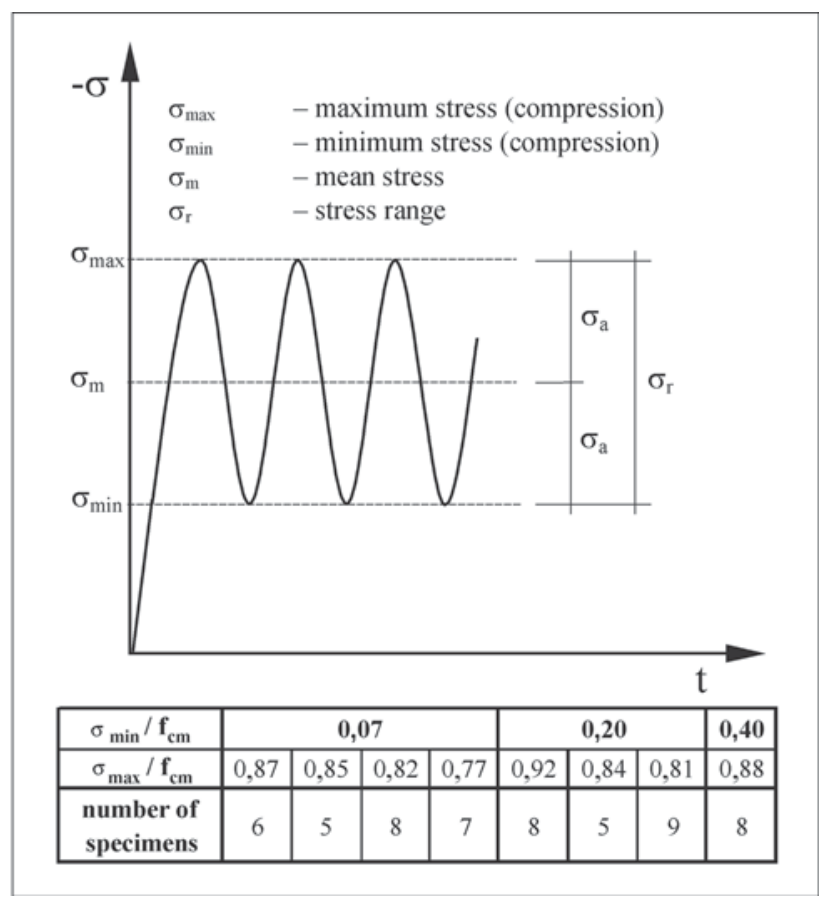

Fig 1. Sinusoidal loading, series of specimens

\subsection{Experimental results of fatigue tests}

Several results can be deduced from the fatigue tests. First, the 'load cycles to failure' can provide information about the fatigue strength of the tested AAC. In addition, damage accumulation during the tests was monitored by applying deformation measurements.

\section{Number of cycles to failure}

In Fig 2, the fatigue performance of $\mathrm{AAC}$ and $\mathrm{LAC}$ is expressed in terms of the number of cycles to failure within a given stress range ( $\mathrm{S} / \mathrm{N}$ curve). The cycles to failure are plotted on a base 10 logarithmic scale, and the stress range is non-dimensionalised by the compressive strength $\mathrm{f}_{\mathrm{cm}}$. Dots in the figure represent repetitions of stress, with a probability of 0,50 for each series. The lines connect points of equal minimum stress.

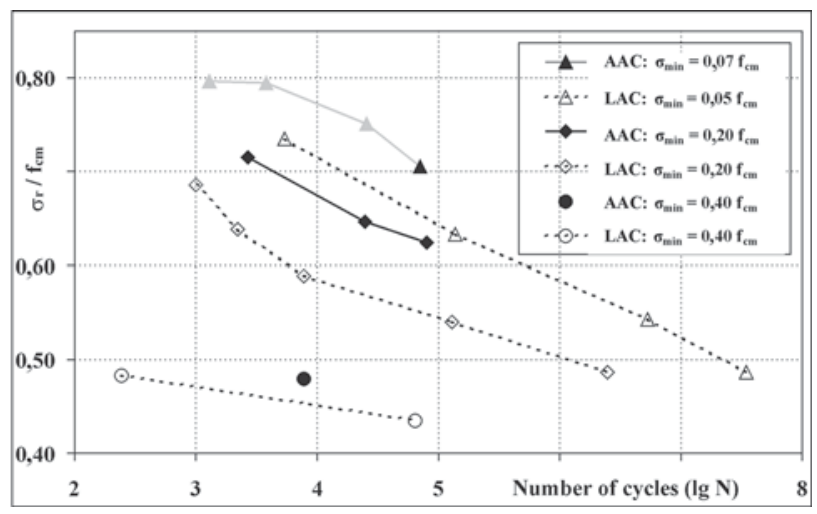

Fig 2. S/N plots for lightweight concrete [4] (LAC) and autoclaved aerated concrete (AAC) 
The form of the $\mathrm{S} / \mathrm{N}$ curve for $\mathrm{AAC}$ is similar to that of other concrete kinds. Fatigue life increases significantly within a low stress range. Only one series could be tested at $\sigma_{\text {min }}=0,40 \cdot \mathrm{f}_{\mathrm{cm}}$. An attempt was made to test a second series at $\sigma_{\max }=0,85 \cdot \mathrm{f}_{\mathrm{cm}}\left(\sigma_{\mathrm{r}}=0,45 \cdot \mathrm{f}_{\mathrm{cm}}\right)$. In this case, failure did not occur within $10^{6}$ load cycles.

Comparing the curves for LAC and AAC within the same stress range, it can be seen that AAC has superior fatigue properties, ie a greater number of cycles (and thus longer load periods) have to be applied within the same stress range to induce failure.

The distance of appropriate lines (excluding $\sigma_{\min }=$ $0,07 \mathrm{f}_{\mathrm{cm}}{ }^{1}$ ) increases as the stress range $\sigma_{\mathrm{r}}$ decreases. In addition, the distance between the lines at higher minimum stress is even greater. This leads to the assumption that, with a constant static stress $\left(\sigma_{\mathrm{r}}=0\right)$, the load duration of AAC is greater than that of lightweight concrete.

It must also be taken into account that the fatigue tests shown in Fig 2 were performed at different loading frequencies. With the exception of one series $\left(\sigma_{\min }=0,40\right.$ $\left.\mathrm{f}_{\mathrm{cm}}\right)$, the frequency used for AAC $(5 \mathrm{~Hz})$ was always lower than for LAC $(10 \mathrm{~Hz})$. Higher frequencies result in a higher number of cycles to failure. It can therefore be deduced that the distances of the lines would become even greater at the same frequency.

The dependence of the number of cycles to failure on loading frequency was determined for normal concrete [5] and lightweight concrete [4]. The results show that the influence is significant, at least at maximum stresses, ie those exceeding $75-80 \%$ of the compressive strength.

The influence of frequency was examined on the basis of one series $\left(\sigma_{\max }=0,87 \cdot \mathrm{f}_{\mathrm{cm}}\right)$. The frequency was reduced to $1 \mathrm{~Hz}$. As shown in Fig 3, this dependence on AAC was determined. At $1 \mathrm{~Hz}$, substantially fewer load cycles to failure had to be conducted at comparable stress levels.

Weigler and Freitag [4] have claimed that scattering in fatigue is mainly due to the scattering of short-

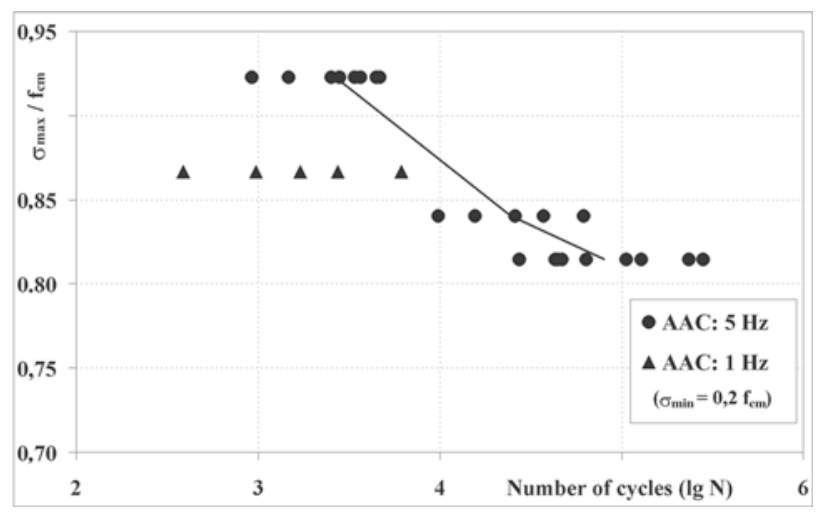

Fig 3. Influence of frequency

\footnotetext{
${ }^{1}$ An exact application of loads was not feasible within the three series at higher maximum stress levels.
}

term strengths. Fig 4 shows this assumption to be justified. Compressive strength tests have already shown comparatively small scattering (with a coefficient of variance of approx $2 \%$ ). This is reflected in the small scattering of the number of cycles to failure of AAC compared with LAC.

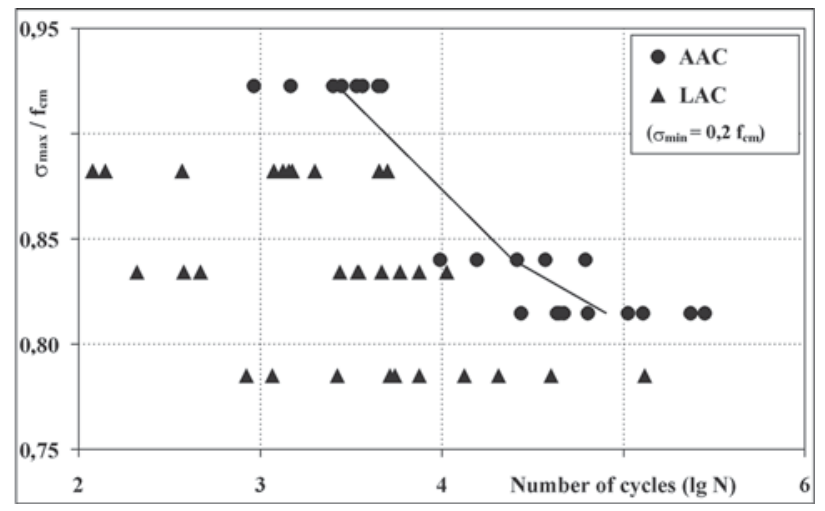

Fig 4. Scattering of numbers of cycles

\section{Deformation behaviour}

Microscopic damage mechanisms lead to macroscopic deformations. Total strains include elastic, plastic and creep deformations. Thus total strains are significantly influenced by load duration or the number of load cycles.

According to [6], load duration is less significant for elastic properties. Thus rigidity appears to be a suitable parameter for evaluating texture condition during fatigue tests.

Fig 5 shows the secant modulus of elasticity versus the normalised cyclic lifetime. The differences of stresses and strains between maximum and minimum load levels (inset of Fig 5) were used for computation purposes.

It must be taken into account that, for technical reasons, the entire specimen length had to be used for deformation measurement. This means that disturbed parts of the specimens near the plates had to be included in the data. The results, however, do not lose their qualitative character as a result.

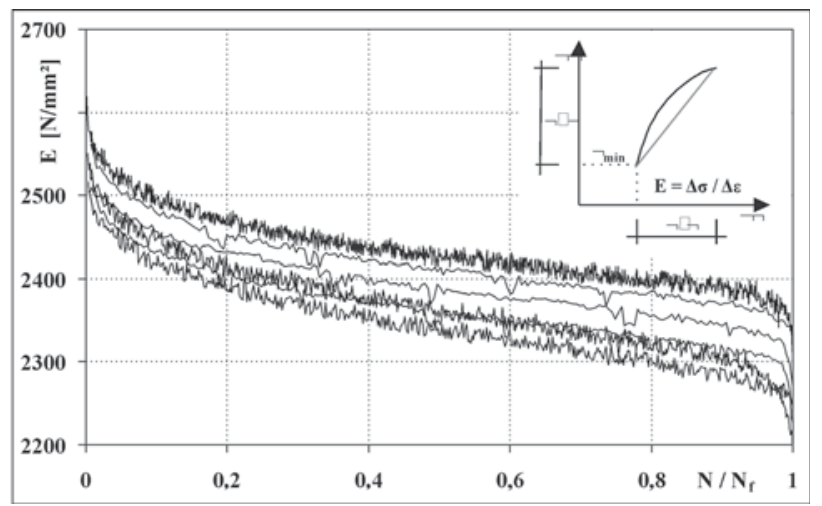

Fig 5. Stiffness degradation (AAC) 
The development of stiffness degradation of AAC during fatigue is similar to that observed for normal and lightweight concrete. As Fig 5 shows, the curves of AAC lie almost on top of each other.

The destabilisation process of AAC can be divided into three characteristic ranges. During the first load cycles, longitudinal strains start to increase sharply. Damage mechanisms result in a significant decrease in the secant modulus.

This is followed by a more stable section in which the decreases in the modulus of elasticity are minimal. This section extends over the largest part of the cyclic life $(80-90 \%)$. Here the decrease in the secant modulus amounts to $\sim 5-10 \%$. These observations can also be made with normal concrete [7], although here the decrease in rigidity is somewhat greater. Furthermore, this section of the cyclic lifetime is slightly smaller for normal concrete $(70 \%)$.

There was a further period of substantial decrease in the secant modulus shortly prior to failure. This may be caused by a larger number of cracks and crack coalescence.

Failure was initiated by diagonal cracks (Fig 6). The influence of the hindrance of lateral expansion near the compression plates can be seen above. "Area one" is the section where the first crack could be seen on the specimen surface. This crack, with a length of $3 \mathrm{~cm}$, occured after 5000 load cycles. There were 30,000 cycles before specimen failure.

Based on the fatigue tests described, it can be concluded that the fatigue of AAC is similar to that of lightweight and normal concrete. This is illustrated by the load cycles to failure, the deformation behaviour and the form of cracking.

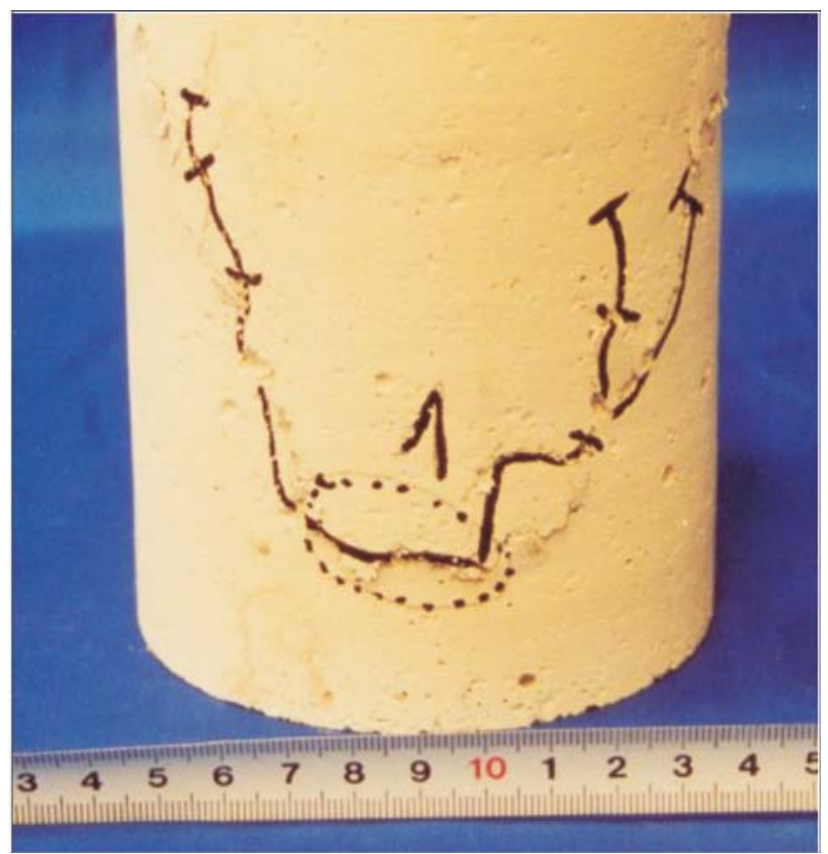

Fig 6. Specimen after fatigue failure (AAC)
To be more precise, AAC showed a decreased sensitivity to fatigue compared with LAC. Especially at low stress ranges, the distance between the $\mathrm{S} / \mathrm{N}$ curves for $\mathrm{AAC}$ and LAC increased. Consequently, the fatigue life (or load duration) for AAC at $\sigma_{\mathrm{r}}=0$ (sustained loading) should also be at a higher stress level. Finally, the value for the sustained loading strength of AAC should exceed $80 \%$ of its short-term compressive strength.

\section{Tests with sustained compressive axial loads}

Further tests applying static loads under conditioned atmosphere $\left(20^{\circ} \mathrm{C}, 65 \%\right.$ relative humidity) were carried out at the Bauhaus-University Weimar, using unreinforced cylinders $(\mathrm{d}=150 \mathrm{~mm}, \mathrm{l}=400 \mathrm{~mm})$ made of AAC. Two different mixtures of AAC (dry density of $5,8 \mathrm{kN} / \mathrm{m}^{3}$, $6,7 \mathrm{kN} / \mathrm{m}^{3}$ ) were tested. The humidity equilibrium was reached after $\sim 200$ days at 2,5 and 3,3 $\mathrm{M} \%$ respectively.

\subsection{Investigation procedure}

First, the compressive strength $\mathrm{f}_{\mathrm{cm}}$ of both series $\left(5,5 \mathrm{~N} / \mathrm{mm}^{2}, \mathrm{COV}=0,03\right.$ and $\left.6,4 \mathrm{~N} / \mathrm{mm}^{2}, \mathrm{COV}=0,01\right)$ was determined by monotonic loading, using the same specimen geometry and loading rate $\left(0,015 \mathrm{~N} / \mathrm{mm}^{2}\right.$ per sec) as for the sustained load tests. In the course of the sustained load tests, stress was kept constant at a given load level. Deformations were measured by strain gauges.

\subsection{Experimental results from sustained load tests}

The results of all the series are shown together below because no differences in the time-dependent material properties appeared. Because of the different compressive strengths, the load levels of each series are shown as ratio of applied stress to mean ultimate stress $\left(\sigma / \mathrm{f}_{\mathrm{cm}}\right)$.

\section{Time to failure}

Fig 7 shows stress in terms of the compressive strength as a function of sustained time to failure on a logarithmic scale.

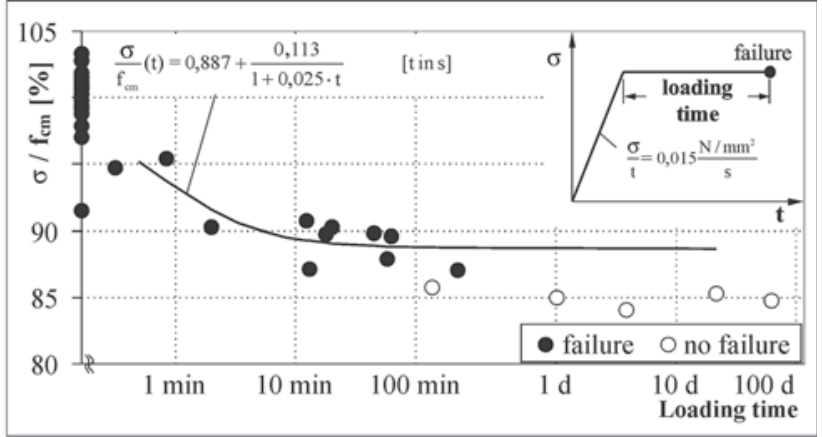

Fig 7. Relation between normalised stress and loading time 
Time measurement began when the appropriate load level was reached, as the inset in Fig 7 illustrates. Thus time for applying loads $(5-7 \mathrm{~min})$ is not included.

From Fig 7 it is visible that some specimens did not fail under the given loads. It can be observed that, for all those specimens that failed, failure occurred within a few minutes. Fig 7 is supplemented by the regression curve of all the specimens that failed. The equation of the regression curve was thus assumed to have the form

$$
\frac{\sigma}{\mathrm{f}_{\mathrm{cm}}}(\mathrm{t})=\mathrm{a}+\frac{1-\mathrm{a}}{1+\mathrm{c} \cdot \mathrm{t}}
$$

$\sigma \quad \ldots$ applied stress

$\mathrm{f}_{\mathrm{cm}}$... mean value of compressive strength

t ... time

a, c ... coefficients

The coefficients were calculated by the least-squares method. For a probability of failure of 0,50 , the equation is

$$
\frac{\sigma}{\mathrm{f}_{\mathrm{cm}}}(\mathrm{t})=0,887+\frac{0,113}{1+0,025 \cdot \mathrm{t}} \quad[\mathrm{tin} \mathrm{s}] .
$$

The regression curve indicates the sustained load strength of AAC to be somewhat above $85 \%$ of the short-term strength. Throughout the tests, specimen failure did not occur at stress levels below $87 \%$ of the short-term ultimate.

\section{Deformations}

Fig 8 shows longitudinal deformations as a function of time.

The data points are supplemented by the values of the normalised stress $\left(\sigma / \mathrm{f}_{\mathrm{cm}}\right)$. Failure occurs when strains are between 3 and 3,5\%. It can be seen that the increase in time-dependent deformations diminishes for stresses which do not exceed about $0,85 \mathrm{f}_{\mathrm{cm}}$.

\section{Comparison of fatigue and sustained loading strength}

The load duration of the static and cyclic tests will now be compared. The simplification of the "load duration" is illustrated in the inset of Fig 9. Cyclic loads are treated as static loads. To be more precise, all parameters that effect cyclic life, such as rate of loading, stress parameters etc, have to be taken into account. A number of interesting aspects nevertheless emerge.

Fig 9 contains a comparison of the static and cyclic tests. In the interests of clarity, only the regression curve for the static tests is shown. The results of the fatigue tests are plotted in the form of maximum stress versus "load duration". Again in the interests of clarity, the individual points are supplemented by the mean number of cycles to failure $(\mathrm{N})$.

It can be seen that sustained loading becomes more critical than cyclic loading at high stress levels. If the

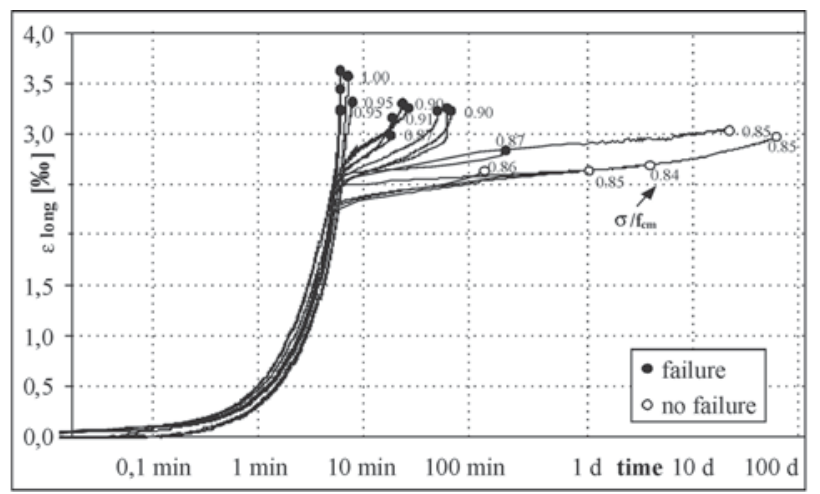

Fig 8. Longitudinal deformations

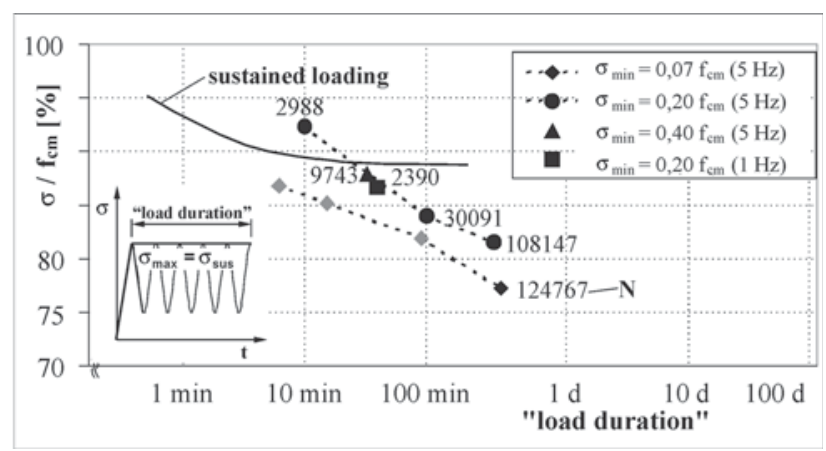

Fig 9. Relation between normalised stress and "load duration" comparison

value of the sustained loading strength were exceeded, sustained loads would lead to failure earlier than fatigue loads (Fig 9). In this context, load range and frequency of loading are not significant factors. This is underlined by the observation that the lines of the various series of differing minimum stresses meet at stress levels close to the sustained load strength. In particular, the series tested at $1 \mathrm{~Hz}(\mathrm{~N}=2390)$ shows the influence of "load duration". The computed load duration corresponds to that of the series at $5 \mathrm{~Hz}$. In the high load area, damage accumulation due to fatigue mechanisms is of secondary importance. Only in case of low stresses (below sustained loading strength) does fatigue exert any significant influence.

One further point relating to the SMITH diagram can be derived from the results of the static tests. The relationship between stress amplitude and mean stress is illustrated for a defined number of cycles to failure. As the mean stress increases, the stress range has to be reduced in order to reach the predicted cyclic lifetime. Cyclic load approaches sustained load at the level where minimum, mean and maximum stress have the same value.

SMITH diagrams are usually plotted for a cyclic lifetime of $2 \cdot 10^{6}$ cycles. This number of cycles was not reached during the tests conducted on AAC. The SMITH diagram is therefore given for $\mathrm{N}=10^{4,85}$. For comparison, Fig 10 is supplemented by the values for LAC. 


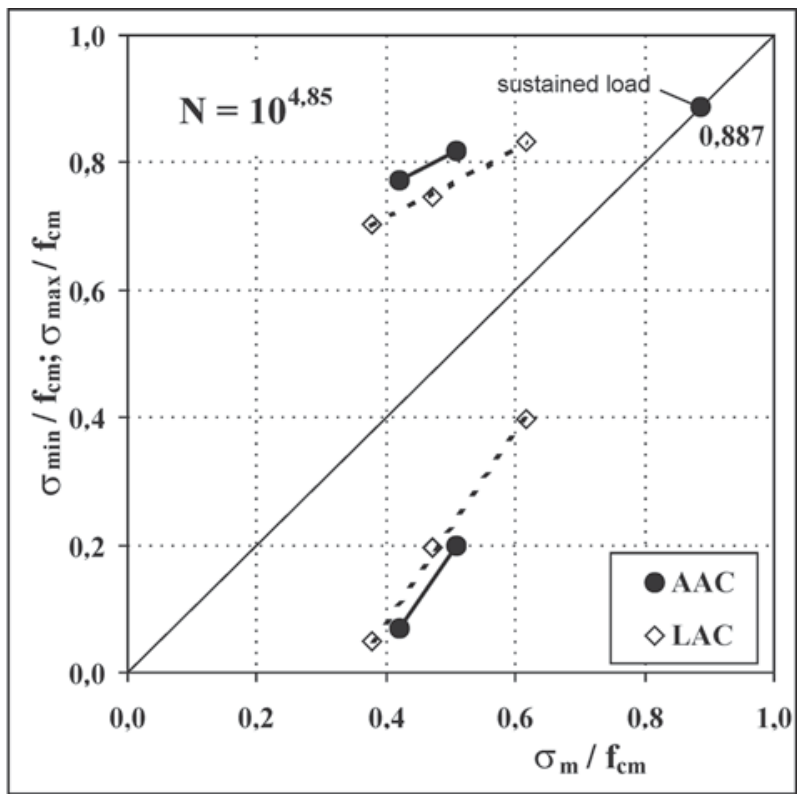

Fig 10. Smith diagram for lightweight concrete (LAC) [4] and autoclaved aerated concrete (AAC)

Comparing AAC and LAC, Fig 10 shows that the lines for AAC lie outside the symmetrical axis. This again underlines the higher fatigue strength of AAC. In addition, the load belonging to a comparable sustained load $\left(\sigma_{\mathrm{r}}=0\right)$ was computed. The associated value $\left(0,887 \cdot \mathrm{f}_{\mathrm{cm}}\right)$ corresponds approximately to the determined sustained loading strength.

A comparison of fatigue and static loading shows the influence of load duration on damage accumulation in AAC. Acceleration of damage accumulation using cyclic loads versus static loads is only possible when loads are below sustained loading strength. Provided that the frequency of loading is $5 \mathrm{~Hz}$, at least 10000 load cycles are needed before specimen failure occurs. In case of higher loads, fatigue is a less significant factor than load duration.

\section{Concluding remarks}

The tests with static and fatigue loads show that the behaviour of autoclaved aerated concrete (AAC) corresponds to that of normal and lightweight concrete. It can be deduced that AAC shows even a greater fatigue resistance than lightweight concrete. It transpires that this is reflected in a higher sustained loading strength for AAC than for lightweight concrete. This is in accordance with the preliminary considerations, a significant influence of the load duration on damage accumulation at high loads was found in case of AAC.

It remains to be seen in which respects long-term loads below the sustained loading strength might lead to significant structural changes affecting the load-bearing capacity. In this context, the dependence of damage accumulation on loading rate, load duration and load history appears to be of great interest.

\section{References}

1. Lusche, M. (1972). A contribution to the fracture mechanism of normal and lightweight concrete under compression (Beitrag zum Bruchmechanismus von auf Druck beanspruchtem Normal- und Leichtbeton mit geschlossenem Gefüge). Schriftenreihe der Zementindustrie, 39. Düsseldorf: Beton - Verlag GmbH.

2. Wittmann, F.; Zaitsev, J. (1974). Deformation and deterioration mechanisms in porous materials under short- and long-term loading (Verformung und Bruchvorgang poröser Baustoffe bei kurzzeitiger Belastung und Dauerlast). Deutscher Ausschuss für Stahlbeton, 232. Berlin: Ernst \& Sohn.

3. Raue, E.; Wehr, G.;Tartsch, E. (2000). Behaviour of autoclaved aerated concrete under cyclical load (Untersuchungen zum Verhalten von Porenbeton unter zyklischer Beanspruchung). Thesis 46, Heft 3, 48-56.

4. Weigler, H.; Freitag, W. (1975). Fatigue behaviour of lightweight concrete (Dauerschwell- und Betriebsfestigkeit von Konstruktions-Leichtbeton). Deutscher Ausschuss für Stahlbeton, 247. Berlin: Ernst \& Sohn.

5. Weigler, H.; Rings, K.-H. (1987). Plain and reinforced concrete under alternating loading (Unbewehrter und bewehrter Beton unter Wechselbeanspruchung). Deutscher Ausschuss für Stahlbeton, 383. Berlin: Ernst \& Sohn.

6. Müller, F. P.; Keintzel, E.; Charlier, H. (1983). Dynamic problems in reinforced concrete construction. Dynamically loaded reinforced concrete (Dynamische Probleme im Stahlbetonbau, Teil 1: Der Baustoff Stahlbeton unter dynamischer Beanspruchung). Deutscher Ausschuss für Stahlbeton, 342. Berlin: Ernst \& Sohn.

7. Holmen, J. O. (1979). Fatigue of concrete by constant and variable amplitude loading. Institut for Betonkonstruksjoner, Bulletin. Nr. 79/1, Trondheim.

\section{AUTOKLAVE ŠUTINTO AERUOTO BETONO NUOVARGIO IR ILGALAIKĖS APKROVOS POVEIKIO EKSPERIMENTINIŲ TYRIMŲ REZULTATAI}

\section{E. Raue, E. Tartsch}

\section{Santrauka}

Betono varginamasis stiprumas yra mažesnis už jo statini stiprumą. Atliekant bandymus pagal tam tikrą metodiką, buvo paspartintas destabilizacijos dèl mikropleišèjimo procesas veikiant varginamajam apkrovimui. Tyrimų tikslas - nustatyti betono stipri veikiant ilgalaikei apkrovai. Autoklave šutinto aeruoto betono varginamasis stiprumas bandytas apkraunant 
nearmuotus betoninius cilindrus cikline apkrova. Nustatyta, kad autoklave šutintas aeruotas betonas yra mažiau jautrus varginamajam apkrovimui nei lengvasis betonas. Varginamieji bandymai buvo papildyti bandymais ilgalaike apkrova. Galima palyginti iš lengvojo ir iprastinio betonų pagamintų bandinių elgsena, esant statinei ir varginamajai apkrovai. Nustatyta žymi apkrovimo trukmès įtaka bandiniams, ypač esant aukštam apkrovimo lygiui.

Raktažodžiai: autoklave šutintas aeruotas betonas, varginamasis stiprumas, stiprumas veikiant ilgalaikei apkrovai, sinusoidinis apkrovimas, standumo mažèjimas, Smito diagrama, stiprumo ir ciklų skaičiaus priklausomybè.

Professor Dr-Ing Habil Erich RAUE has been working since 1976 at the Bauhaus-University Weimar, Germany. He is the leader of the Dept of Reinforced Concrete Structures. He has participated in different standard committees and is actually a member of the Committee for Aerated Concrete in the German Institute for Construction Engineering (DIBt) and of the Collaborative Research Centre 524 of the German Research Foundation (DFG). He teaches reinforced and prestressed concrete design, non-linear analysis of $\mathrm{r} / \mathrm{c}$ structures and structural design. He conducted research in different domains: non-linear and time-depending behaviour of $\mathrm{r} / \mathrm{c}$ structures under low-cyclic and impact loading, structural analysis based on non-linear optimisation methods, composite structures and alternative reinforcement, structural safety and reliability, shell structures. He has published about 170 papers and is co-author of 3 monographs.

Enrico TARTSCH is a PhD student at the Dept of Reinforced Concrete Structures at the Bauhaus-University in Weimar. He did his diploma in civil engineering in 2000. He has published 7 research articles including works on timedependent deformation behaviour of autoclaved aerated concrete under cyclic and sustained loads. 